\title{
COST EFFICIENCY OF RICE FARMING IN INDONESIA: STOCHASTIC FRONTIER APPROACH
}

\author{
Reynaldo Angga Siagian', Widyono Soetjipto \\ ${ }^{1}$ Graduate Program Faculty of Economics, University of Indonesia, Indonesia \\ ${ }^{2}$ Departement of Economics, University of Indonesia, Indonesia \\ Corresponding author: reynaldo25angga@gmail.com
}

\begin{abstract}
The main objectives of the study are to estimate the farm-specific cost efficiency of rice production in Indonesia using Cost Frontier model and to identify and measure the impacts of different factors associated with the cost efficiency of rice farmers. The study employed farm level cross-sectional data for the years 2010 and 2016. The cost of irrigation, fertilizer, and labor were found to contribute significantly to the cost-efficiency of rice farmers. The average cost efficiency of rice production in 2016 is 83 percent, this result is higher than in 2010. This indicates a good potential for increasing rice output by 17 percent with the existing technology. The model claims that smaller land, more plot in the land, three-time crop planting a year, and diversification significantly contribute to cost efficiency in farm production.
\end{abstract}

Keywords: Agricultural farmers, stochastic frontier function, Indonesian rice policy, cost-efficiency

http://dx.doi.org/10.21776/ub.agrise.2020.020.1.2

Received 11 Juli 2019

Accepted 11 December 2019

Available online 31 January 2020

\section{INTRODUCTION}

As the owner of a land area of 160 million hectares, however, Indonesia still a net importer of grains, horticulture, and livestock production. The instability of food prices since 2008 has led to a renewed emphasis on food security (Asian Development Bank, 2015). The problem with food security in Indonesia these days is the high population level, while the agricultural household is decreasing and also the threat of land-use change due to large-scale plantations of palm oil and rubber. The area of paddy fields in Indonesia from year to year does not grow much, wherein 2010 paddy fields in Indonesia ranged from 8,106,562 hectares and in 2016 only became at $8,186,470$ hectares (Land agricultural statistics, 2017). As indicated by the World Bank (2010) since the 1990s agricultural production in Indonesia has been characterized by stagnation and low productivity due to years of declining private and public sector investment in supporting the agricultural economy. And also many small farmers often produce without using the benefits of modern tools or quality seeds (FAO, 2018).

Sadoulet and Janvry (1995) explained policymakers in boosting growth in the agricultural sector need to increase efficiency through technical efficiency and also increase productivity through technical changes in the transfer of new technology or research. Nkegbe (2018) also said agricultural productivity can also be improved through several ways including adopting new technologies, increasing the use of inputs and also increasing the technical efficiency of the farmers.

It is said that even though from the production function side the farmer is efficient in using his inputs to produce certain outputs but it can be from the cost side the producer cannot allocate the inputs they use effectively based on the available input prices. Tu and Trang (2016) stated that it is very important to consider the ability of farmers to reduce production costs rather than increase productivity because a decrease in costs is one of the three components that provide higher profits to rice farmers. Also according to Belbase and Grabowski 
(1985), it is more efficient in using costs to increase productivity with existing technology than using new technology.

Cost efficiency is a ratio of minimum production costs that allows the level of inefficiency to the actual total cost (Coelli et al., 2005). According to Kumbhakar and Lovell (2000), the cost frontier can be written in the following form:

$$
C_{i} \geq C\left(Y_{i}, P_{i} ; \beta\right) e^{v_{i}}
$$

Where $C_{t}$ represents the observed cost of individual $i$, and $\mathrm{P}_{\mathrm{i}}$ is the price of the production input, $Y_{i}$ is the volume value of the output obtained at time i, $\beta$ is the estimated parameter and $e^{v_{i}}$ is symmetrical, identical and freely distributed which is indicated as a noise effect not under the control of the farmer.

To find out the estimation of cost-efficiency can be seen in Figure 1, it is assumed that a producer uses two inputs $\left(\mathrm{X}_{1}\right.$ dan $\left.\mathrm{X}_{2}\right)$ to produce an output. Isoquant curve $\mathrm{SS}$ describe producers who technically efficient or production limit that measures technical efficiency. If the producer uses an input combination described at point $A$ to produce a certain number of outputs, then the technical inefficiency of the producer is indicated by the distance from BA. This distance shows the ability to reduce proportionally the combined inputs without sacrificing output values, which is usually defined as the ratio of percentage of $\mathrm{OB} / \mathrm{OA}$.

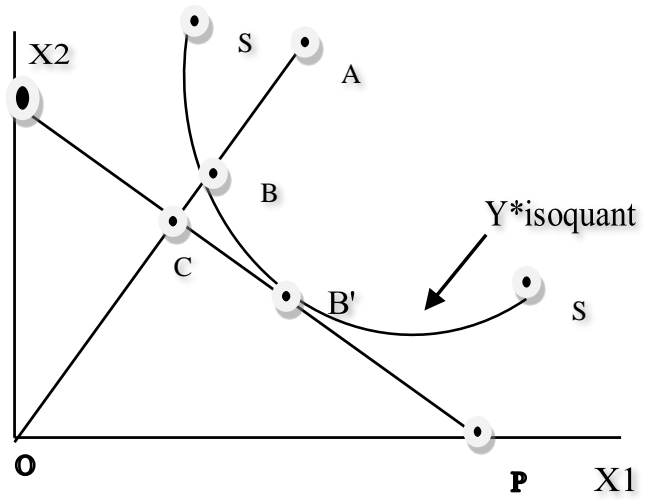

Figure 1. Measurement of Cost Efficiency

Based on the picture above, the cost efficiency of the producer can be estimated if input prices are available. The isocost line PP represents the minimum cost limit on the vector of input prices. If $\mathrm{w}$ and $\mathrm{x}$ represent the input price vector and the vector observed at the input is associated with point $\mathrm{A}$, then $\mathrm{x}$ 'which represents a vector of the costminimizing input is associated at point $\mathrm{C}$. Value $\mathrm{B}^{\prime}$ is an individual who is efficient in applying the input and can also efficiently minimize costs due to the purchase of certain inputs. Producers who produce are in the cost frontier will be called efficient, and producers operating above the cost frontier are called inefficient (Kumbhakar dan Lovell, 2000).

This research will discuss cost efficiency among farmers in Indonesia. In Indonesia, research on efficiency has often been studied (Wardana, Yamamoto, dan Kano, 2017; Heriqbaldi et al., 2014; Haryanto, Talib, dan Salleh, 2015; Alwarritzi, Nanseki, dan Chomei, 2015). However, many previous studies looked at the production function or technical efficiency, while this study specifically discussed the cost efficiency using the Stochastic Frontier approach in Indonesia. In addition, this study will compare the cost efficiency of rice farmers based on time in the 2010 and 2016 data, where the two years can represent differences in efficiency between two different government periods in Indonesia.

So, this research would like to see the Cost Efficiency of farmers in Indonesia, the difference in cost efficiency between times, as well as social, economic and land characteristics of farmers.

\section{RESEARCH METHODS}

This study uses data from the National Farmers Panel (PATANAS) with observation periods in 2010 and 2016 using the stochastic frontier method. After getting the relationship between the two frontier variables the model can calculate the cost efficiency among farmers. The value of Cost efficiency is then used as the dependent variable to regress with the independent socio-economic variable among farmers to see what determines inequality among farmers. The regression used will use Stata 14.1 in operation.

Following the estimation model from Ogundari and Ojo (2007) and Maurice, Adamu, dan Joseph (2015) the empirical model used in this study is the Cobb-Douglas Stochastic Frontier model with the cost stochastic frontier function. Explicitly the function of Cobb-Douglas costs for rice plants in Indonesia is:

$$
\begin{aligned}
\ln C= & \alpha_{0}+\alpha_{1} \ln X_{1}+\alpha_{2} \ln X_{2}+\alpha_{3} \ln X_{3}+ \\
& \alpha_{4} \ln X_{4}+\alpha_{5} \ln X_{5}+\alpha_{6} \ln X_{6}+\alpha_{7} \ln X_{7}+ \\
& \left(V_{i}+U_{i}\right)
\end{aligned}
$$


Where:

$\mathrm{C}=$ total production costs $(\mathrm{C})$

$\mathrm{X} 2$ = labor costs

$\mathrm{X} 3$ = seedling costs

$\mathrm{X} 4$ = irrigation costs

$\mathrm{X} 5=$ costs of chemical fertilizers

$\mathrm{X} 6=$ the cost of chemical drugs

$\mathrm{X} 7=$ production quantity

$\mathrm{Ui}=$ specific characteristics of farmers and environment related to cost inefficiency

$\mathrm{Vi}=$ Statistical disturbance term.

To identify what affects technical efficiency in the cost function, Efficiency will be seen as a dependent variable with the socio-economic and land characteristics of the farmer being the independent variable. In this research Tobit regression model is used to see what determines the value of cost-efficiency. Torbit regression has two advantages, first for ease of manipulation in regression and related scores on efficiency between 0 and 1 which can be calculated using Tobit (Adeyemi, Okurawa, Ikudaisi, 2017).

The regression model becomes:

$$
\begin{gathered}
C E_{i}=\delta_{0}+\delta_{1} T_{1}+\delta_{2} T_{2}+\delta_{3} T_{3}+\delta_{4} T_{4}+\delta_{5} T_{5} \\
+\delta_{6} T_{6}+\delta_{7} T_{7}+\delta_{8} T_{8}+\delta_{9} T_{9} \\
+\delta_{10} T_{10}+e
\end{gathered}
$$

Where:

$\mathrm{CE}_{\mathrm{i}}=$ Cost efficiency

$\mathrm{T}_{1}=$ Age of head of household

$\mathrm{T}_{2}=$ Education of the head of the household

$\mathrm{T}_{3}=$ number of household members

$\mathrm{T}_{4}=$ Dummy government assistance that has been received in the past year $(1=$ accept government assistance, $0=$ no);
$\mathrm{T}_{5}=$ access to credit $(1=$ have access to credit, $0=$ no);

$\mathrm{T}_{6}=$ land ownership $(1=$ own property, $0=$ rent $)$

$\mathrm{T}_{7}=$ Total planting period per year

$\mathrm{T}_{8}=$ Area

$\mathrm{T}_{9}=$ Total plot of land

$\mathrm{T}_{10}=$ Land Diversification $(1=$ diversified land, $0=$ no).

\section{RESULTS AND DISCUSSION}

\section{Descriptive Analysis of Stochastic Frontier}

This paper uses the stochastic frontier approach to estimate the cost function using data from two periods at the household level. The description of input data for 2010 and 2016 can be seen in Table 1 . The average total production cost has increased from 2010 to 2016 around $40 \%$ more. And In 2016 there was a significant increase in input prices in labor, this is good because there is an increase in welfare, especially for farmworkers in the rural area. The average price of fertilizer costs, seed costs, costs of chemical drugs such as herbicides and pesticides, costs for irrigation in the study area also increased very high in 2016 compared to 2010. Even though from the input production side there was an increase in costs but it was also followed by an increase in production output by almost $20 \%$ between years. The production quantity in 2016 has increased by 6403 kilograms on average per household compared to 2010 around 5215,829 kilograms on average.

Table 1. Descriptive Analysis of Stochastic Frontier

\begin{tabular}{lrrrrrr}
\hline \multirow{2}{*}{ Variable } & \multicolumn{2}{c}{ Obs } & \multicolumn{2}{c}{ Mean } & \multicolumn{2}{c}{ Std. Dev. } \\
\cline { 2 - 7 } & 2010 & 2016 & 2010 & 2016 & 2010 & 2016 \\
\hline Production costs & 379 & 344 & $11,457,146$ & $20,655,369$ & $4,272,733$ & $5,558,392$ \\
Labor costs & 379 & 344 & $1,476,342$ & $2,253,496$ & $2,432,763$ & $3,255,041$ \\
Seed costs & 379 & 344 & $565,778.50$ & $813,120.20$ & $407,945.4$ & $458,909.9$ \\
Irrigation costs & 379 & 344 & $178,355.30$ & $377,978.93$ & $320,336.3$ & $900,049.2$ \\
Fertilizer costs & 379 & 344 & $1,788,861$. & $2,959,476$ & $844,293.1$ & $1,276,363$ \\
Total Production & 379 & 344 & $5,215.83$ & 6403.666 & $3,977.621$ & $5,544.93$ \\
Pesticides Costs & 379 & 344 & $1,151,675$ & $2,421,577$ & $751,840.3$ & $1,638,504$ \\
\hline
\end{tabular}

Source: primary data used

Furthermore, all samples are estimated separately each year and use pooled data as shown in Table 2. The separation of estimation results is expected to help provide a broader description of the results of this study.

\section{Stochastic Cost frontier analysis}

All the coefficients of the cost stochastic frontier function for agriculture in Indonesia in the two years are statistically significant. This shows the relationship between input prices and output volume 
with the cost function on rice farming in the study area.

For variable land rent in 2010 and 2016, it is very significantly positive and significant towards production costs. Labor costs have a positive effect on rising costs in 2010 and in 2016. This makes the increase in labor costs increase all production costs. This is consistent with the theory of Hossain and Hussain (1977) which states that farmers who have small land use more labor input than other production inputs and in traditional agriculture land production is still influenced by variations in labor rather than material input. We know that farmers' land ownership in Indonesia is mostly only around 0.6 hectares and in addition small farmers in Indonesia still use traditional systems in carrying out their production.

Although this fertilizer subsidy policy has been discussed and developed from 2003 but there are also some obstacles in its implementation. Yanto, Sihombing, and Kusuma (2013) state that the selling price of subsidized fertilizer at the retailer level is sometimes not in accordance with the Highest Retail Price (HET) set by the Indonesian government, where the selling price of all types of subsidized fertilizer is above the HET with an increase in average prices ranging from $12 \%$ to $20.86 \%$. Infrastructure development in rural areas, especially road construction, can improve distribution of production inputs in agricultural areas.

Irrigation costs have a positive and significant effect on the costs of farmers in 2010 and in 2016. The government has recently rehabilitated and promoted the construction of irrigation and dams for use in the agricultural sector. Regarding expenditure on irrigation land, it is stated that there is a paradigm where water is not purchased, but it needs processing so that it can be utilized and allocated to replace the costs of operating and maintaining irrigation networks (Noorvy dan Suhudi, 2009).

The value of fertilizer coefficient is quite large in influencing production costs in 2016. The contribution of fertilizer costs to total production costs in Indonesia ranges from $15-30 \%$. This means that the costs of agricultural production in Indonesia in recent years largely depend on the costs of agricultural fertilizers (Maulana dan Rachman, 2009). Currently, many Indonesian farmers use subsidized fertilizers. Subsidized fertilizers are fertilizers whose procurement and distribution are managed by the Highest Retail Price (HET) (Yudhari, 2016). In table 2.4 it can be seen that there has been an increase in fertilizer consumption from 2010 to 2016 which has a very significant effect on output production in those years.

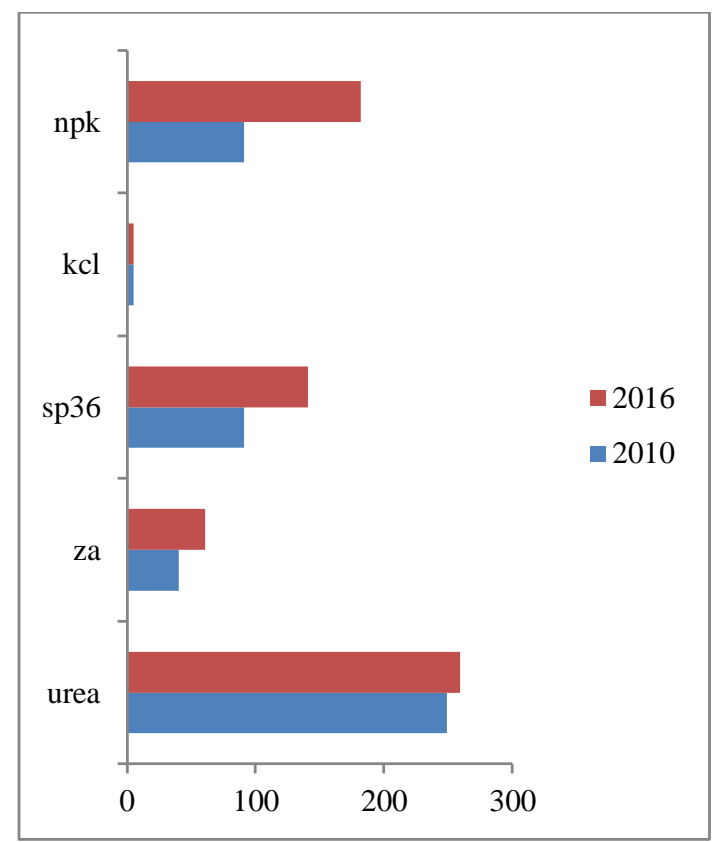

Figure 2. Fertilizer Consumption (Kg)

The cost of seedlings is positive but not significant in influencing the cost of producing agricultural households between years. The cost of agrochemicals does not significantly affect the level of production costs in 2010 and 2016. While the amount of production is positive and significantly affects production costs in 2010 .

The level of efficiency by looking at recent studies (Laha and Kuri, 2011) can be divided based on the level of efficiency with i) very efficient $\geq$ 0.90 , ii) quite efficient: $0.70 \leq \mathrm{TE}<0.90$, iii) inefficient: TE $<0.70$. From table 4.3 can be seen in 2010 and 2016 farmers who are below the inefficient number has decreased dramatically from around 107 farming families to only 2 households. In 2010 farmers still had to increase efficiency by $25 \%$ to achieve the best efficiency. In 2016 the value of efficiency increased with a value of 0.857 which only requires around $15 \%$ for the best cost effeciency. 
Table 2. Estimasi Stochastic Cost Function

\begin{tabular}{lcccc}
\hline \multirow{2}{*}{ Variable } & \multicolumn{2}{c}{2010} & \multicolumn{2}{c}{2016} \\
\cline { 2 - 5 } & Coefficient & SE & Coefficient & SE \\
\hline Labor costs & $0.0118374 * * *$ & 0.0016257 & $0.0073715^{*} * *$ & 0.0013911 \\
Seed costs & 0.0138576 & 0.0143346 & 0.009485 & 0.011422 \\
Irrigation costs & $0.0091129 * * *$ & 0.0019081 & $0.0028615 *$ & 0.0015114 \\
Fertilizer costs & -0.0094257 & 0.0116423 & $0.3471515^{*} * *$ & 0.0394022 \\
Pesticides costs & 0.0121072 & 0.0074735 & -0.0020639 & 0.0112461 \\
Total production & $0.0764688^{*} * *$ & 0.0220176 & 0.0035912 & 0.0174288 \\
Constant & $15.53936 * * *$ & 0.2195538 & $11.48169 * * *$ & 0.607878 \\
\hline Number of households & \multicolumn{2}{c}{379} & & 344 \\
Lamda & \multicolumn{2}{c}{1.694755} & 0.8426842 \\
Sigma Square & \multicolumn{2}{c}{0.1054306} & 0.0981643 \\
Log likelihood & \multicolumn{2}{c}{-116.27898} & -35.819169 \\
\hline
\end{tabular}

* Significance at 10\%, ** Significance at 5\%, *** Significance at $1 \%$

Source: Primary data analyzed

Table 3. Efficiency value

\begin{tabular}{ccc}
\hline $\begin{array}{l}\text { Effeciency } \\
\text { Level }\end{array}$ & 2010 & 2016 \\
$\leq 0.40$ & 4 & 0 \\
$0.41-0.50$ & 13 & 0 \\
$0.51-0.60$ & 28 & 0 \\
$0.61-0.70$ & 62 & 2 \\
$0.71-0.80$ & 145 & 49 \\
$0.81-0.90$ & 118 & 257 \\
$0.91-1.00$ & 10 & 36 \\
Total & 379 & 344 \\
Mean & 0.75164 & 0.8572 \\
\hline
\end{tabular}

Source: Primary data analyzed

\section{Descriptive Analysis of Factors Affecting Cost Efficiency}

Characteristics of agricultural households can be seen in table 4.4. In terms of age, farmers in Indonesia are growing older, with an average age of 49 in 2010 and in 2016 increasing to an average of 53 years. This shows the lack of young workers entering the agricultural sector and there has been no transition from generation of older farmer to young workers. To see the impact of farmers' human resource capabilities on land productivity, this study includes the education level variables of farmer household heads. In terms of education, there is no significant increase in every year where Indonesian farmers on average only reach junior high school level. Farmer household members can become labor supply on agricultural land, where the average number of household members of farmers in Indonesia is 4 people.

For dummy farmers who receive direct assistance from the government there has been a decline from 2010 to 2016 by $43 \%$ to $36 \%$. Access to credit on average increases between years of observation, which means that there is an increase in access from farmers to credit institutions. Even so, there is still a lack of financial institutions such as banks in agricultural areas in Indonesia. In addition, the procedure of borrowing credit is very difficult and in the absence of appropriate guarantees to credit institutions, farmers prefer not to use credit (Shah et. al, 2008). Land ownership is already quite high where around $70 \%$ of the survey already has its own land. Furthermore, on average farmers grow rice in their fields twice a year.

Meanwhile, Indonesian farmers have an average land area of 0.4 to 0.5 hectares which is relatively small. For the average number of plots or land fragmentation, Indonesian farmers have between 3 and 4 plots on their land. While the diversification of crops carried out by farmers on their land in 2010 was greater than in 2016.

\section{Factors Affecting Cost Efficiency}

The estimation results of the cost efficiency determinant factors can be seen in Table 4.5. The age of the head of the household was negative and not significant in 2010, and in 2016 it was also not significant in influencing cost efficiency. Positive values in the age of farmers occur when older household heads are better able to adapt to the use of agricultural production inputs because of their experiences (Pradhan and Mukherjee, 2018).

The education of household heads is positive in 2010 and in 2016, but both have no significant effect on the value of efficiency. The number of family members has a negative effect on efficiency in 2010 and is positive in 2016 but not significantly between 
years of observation. Negative values indicate that the smaller the number of household members will reduce inefficiency in the use of production input costs. Government assistance in 2010 and 2016 did not significantly affect the cost of efficiency of farmers.

Table 4. Descriptive analysis of cost efficiency

\begin{tabular}{lrrrrrr}
\hline \multirow{2}{*}{ Variable } & \multicolumn{2}{c}{ Obs } & \multicolumn{2}{c}{ Mean } & \multicolumn{2}{c}{ Std. Dev. } \\
\cline { 2 - 7 } & 2010 & 2016 & 2010 & 2016 & 2010 & 2016 \\
\hline Age of household head & 379 & 344 & 49.59103 & 53.43605 & 9.647437 & 9.436699 \\
Education head of household & 379 & 344 & 7.403694 & 7.645349 & 3.901307 & 4.176406 \\
Household size & 379 & 344 & 4.28496 & 4.159884 & 1.535492 & 1.515908 \\
Goverment Assistance & 379 & 344 & 0.4353562 & 0.3633721 & 0.496459 & 0.4816713 \\
Access to credit & 379 & 344 & 0.2005277 & 0.2994186 & 0.4009245 & 0.4586705 \\
Land Ownership & 379 & 344 & 0.7783641 & 0.7761628 & 0.4158964 & 0.4174214 \\
Amount of planting per year & 379 & 344 & 0.182058 & 2.072674 & 0.3864025 & 0.337989 \\
Land & 379 & 344 & 0.4496935 & 0.5061599 & 0.3325446 & 0.4406509 \\
Plot & 379 & 344 & 2.456464 & 2.422741 & 1.903792 & 1.321994 \\
Land diversification & 379 & 344 & 0.5461741 & 0.3982558 & 0.4985215 & 0.4902518
\end{tabular}

Source: Primary data analyzed

Access to credit in 2010 was negative at 0.04 and significant at $1 \%$ but not significant in 2016. Access to credit should help farmers develop their agricultural land by providing better quantity and quality inputs. However, due to the improper use of credit funds, the credit does not affect land productivity. While the value of own land ownership in each year of observation has a negative and not significant impact on efficiency. Negative values on the results of this study can be interpreted as farmers who have leased land that is more efficient in managing production costs.

Tabel 5. Cost efficiency estimation

\begin{tabular}{lrrrr}
\hline \multirow{2}{*}{ Variable } & \multicolumn{2}{c}{2010} & \multicolumn{2}{c}{2016} \\
\cline { 2 - 5 } & \multicolumn{1}{c}{ Coefficient } & \multicolumn{1}{c}{ SE } & \multicolumn{1}{c}{ Coefficient } & \multicolumn{1}{c}{ SE } \\
\hline Age of household head & -0.0006937 & 0.0006109 & $1.25 \mathrm{e}-06$ & 0.0002752 \\
Education of household head & 0.0019972 & 0.001521 & -0.0000787 & 0.0006279 \\
Household size & -0.0051833 & 0.0037052 & 0.0000568 & 0.0016153 \\
Goverment Assistance & 0.0070157 & 0.0118923 & -0.0038762 & 0.0052724 \\
Access to credit & $-0.0400294 * * *$ & 0.0139127 & 0.0073699 & 0.0055109 \\
Land Ownership & -0.0189347 & 0.013868 & -0.0029642 & 0.0062779 \\
Amount of planting per year & $0.0739232 * * *$ & 0.0150215 & $0.020832 * * *$ & 0.007155 \\
Land & $-0.0404664 * *$ & 0.0179018 & $-0.009478 *$ & 0.0054916 \\
Plot & 0.0026225 & 0.0031251 & $0.0041636 * *$ & 0.0019065 \\
Land diversification & $0.0262028 * *$ & 0.0118096 & $-0.0091885 *$ & 0.0051997 \\
Constant & 0.7971057 & 0.041212 & $0.8143217 * * *$ & 0.0237856 \\
\hline Number of households & & 379 & & 344 \\
$\Sigma$ & 0.1066971 & 0.0038848 & 0.0440204 & 0.0016853 \\
LR chi2 & & 51.10 & & 25.35 \\
Prob > chi2 & & 0.0000 & & 0.0047 \\
Pseudo R2 & & -0.0906 & & -0.0223 \\
Log likelihood & & 307.46995 & & 580.7185 \\
\hline Source: Primary data analyzed & & & \\
\hline
\end{tabular}

Source: Primary data analyzed 
The number of planting periods in the two years of observation has a positive and significant value on the efficiency of the use of costs. Farmers who pursue higher output values can optimize their land by planting three times a year and make efficiency in the use of costs.

The size of land has a negative effect on the cost efficiency of -0.040 and its significance is $5 \%$ in 2010. While the land area also affects cost efficiency in 2016 it is negative at -0.014 where the significance is $10 \%$. This means that small-sized land is more efficient than large-sized ones. In Indonesia most farmers only have land between 0.4 to 0.5 hectares and are classified as small-sized land. This makes farmers more experienced in processing production on a small land.

The plot describes the intensity of agricultural land. It was seen that the plot had a positive effect of 0.005 in 2016 on cost efficiency. This means that farmers who have more distribution of plots on their land are more efficient in spending costs.

Diversification on land has a positive effect on cost efficiency of 0.026 and is significant at $5 \%$ in 2010. While it is negative and not significant in 2016. Positive value for cost efficiency can occur because farmers use their production inputs in one field to be used for rice farming and other plants that cause production on land to be very efficient compared to production input.

\section{CONCLUSION}

The estimation results show that production costs are positively affected by irrigation costs, fertilizer costs, and labor costs. This suggests that the decline in fertilizer prices, more affordable irrigation technology, and a reduction in labor salaries reduces production costs from rice field farms.

There was an increasing trend from 2010 to 2016, including an increase in the total amount of rice production on average and also the cost efficiency which increased by $10 \%$.

The use of credit by farmers negatively affected in 2010 but was positive in the following year. A more frequent planting period on agricultural land in one year shows a positive value for efficiency. Likewise, the relationship to the land area of farmers that shows smaller land is more cost-efficient. Land with more plots positively affects cost efficiency. While efficiency is seen when farmers use a diversified system in their land production.

\section{REFERENCES}

Adeyemi, B.B., Okoruwa, V.O., \& Ikudaisi, A. (2017). Cost efficiency among rice millers in Southwest Nigeria. International Journal of Social Economics, Vol. 44 Issue: 12, pp.24502465.

Alwarritzi, W., Nanseki, T., \& Chomei, Y. (2015). Analysis of the Factors Influencing The Technical Efficiency Among Oil Palm Smallholder Farmers in Indonesia. Procedia Environmental Sciences, 28(SustaiN 2014), 630-638.

Belbase, K., \& Grabowski, R. (1985). Technical Efficiency in Nepalese Agriculture. Journal of Development Areas, 19(4):515-525.

Coelli, T. J., Rao, D. S. P., O’Donnel, C. J. \& Battese, G. E. (2005). An Introduction to Efficiency and Productivity Analysis. New York: Springer.

FAO. (2018). Small Family Farms Country Factsheet. Indonesia: FAO.

Haryanto, T., Talib B.A., \& Salleh N. H. M. (2016). Technical Efficiency and Technology Gap in Indonesian Rice Farming. Agris on-line Papers in Economics and Informatics Volume VIII, Number 3.

Heriqbaldi, U., Purwono, R., Haryanto, T., \& Primanthi M.R. (2015). An Analysis of Technical Efficiency of Rice Production in Indonesia. Asian Social Science; Vol. 11 , No. 3.

Hossain, M., \& Hussain, M. (1977). Farm Size, Tenancy and Land Productivity: An Analysis of Farm Level Data in BangladeshAgriculture. The Bangladesh Development Studies, Vol. 5, No. 3 , pp. 285-348.

Kumbhakar, S. C. \& Lovell, K. C. A. (2000). Stochastic Frontier Analysis. Cambridge: Cambridge University Press.

Laha, A., \& Kuri P.K. (2011). Measurement of Allocative Efficiency in Agriculture and its Determinants: Evidence from Rural West Bengal, India. International Journal of Agricultural Research 6 (5): 377-388.

Maulana, A., \& Rachman, B. (2009). Evaluasi Kebijakan Sistem Distribusi dan Efektifitas Harga Eceran Tertinggi (HET) Pupuk di 
Tingkat Petani. Bogor: Pusat Analisis Sosial Ekonomi dan Kebijakan Pertanian .

Maurice, D.C., Adamu, Y., Joseph, M. (2015). Analysis of Cost Efficiency in Food Crop Production Among Small-Scale Farmers in Adamawa State, Nigeria. Global Journal of Agricultural Sciences Vol. 14, 17-25.

Nkegbe, P. (2018). Credit access and technical efficiency of smallholder farmers in Northern Ghana:Double bootstrap DEA approach. Agricultural Finance Review , 626-639.

Noorvy, D.K., \& Suhudi. (2009). Penentuan Harga Air Irigasi pada Daerah Irigasi Lintas Kabupaten, DAS Ngasinan - Ngrowo Kabupaten Tulungagung dan Trenggalek. Buana Sains Vol. IX (2), 166.

Ogundari, K. \& Ojo S.O. (2005). Determinants of technical efficiency in mixed crop food production in Nigeria: A Stochastic Parametric Approach. East Africa Journal of Rural Development Vol. 21(1), 15-22.

Pradhan, K.C., \& Mukherjee, S. (2018). Examining Technical Efficiency in Indian Agricultural Production Using Production Frontier Model. South Asia Economic Journal 19(1) , 22-42.

Quincieu, E. (2015). Summary of Indonesia's Agriculture, Natural Resources, and Environment Sector Assestment. ADB Papers in Indonesia, No. 8.
Sadoulet, E., \& Janvry, A.d. (1995). Quantitative Development Policy Analysis. Baltimore MD: The Johns Hopkins University Press.

Shah, M.K., Khan, H., Jehanzeb, K., Khan, Z. (2008). Impact of agricultural credit on farm productivity and income of farmers in mountainous agriculture in Northen Pakistan: a case study of selected village in district Chitral. Agric, 24.

Tu, V.H., \& Trang, N.T. (2016). Cost Efficiency of Rice Production in Vietnam: An Application of Stochastic Translog Variable Cost Frontier. Asian Journal of Agricultural Extension,Economics \& Sociology 8(1) Article no.AJAEES.19745 ISSN: 2320-7027, $1-10$.

Wardana, F.C., Yamamoto, N., \& Kano, H. (2017). Profitability Analysis of Small-Scale Farmers in Indonesia a Case Study of Hand Tractor use in Jember Regency. The Social Sciences, 12 , 2224-2229.

World Bank. (2010). World Development Report 2010 : Development and Climate Change. Washington, DC: World Bank.

Yanto, R.A., Sihombing, L., \& Kusuma, R.I. (2013). Analisis Perbedaan harga pembelian dan kelangkaan pupuk bersubsidi di kabupaten Karo. Jurnal Usu , Vol 2, No 3.

Yudhari, D. (2016). Pemasaran pupuk bersubsidi pada Pt Pupuk Kaltim di Kecamatan Baturiti Kabupaten Tabanan. Jurnal Unud. 